\title{
SWOT Analysis in the Shrimp Cultivation Business a Case Study on MRA Shrimp Tegal, Indonesia
}

\author{
Mukhamad Roykhan Azmi, Dessy Isfianadewi
}

\begin{abstract}
The progress in the business from the fisheries sector start to emerge a promising business, that is the Vannamei Shrimp business. This also makes MRA Shrimp join in to take the advantage of this market. SWOT analysis is a form of evaluation of all the strengths, weaknesses, opportunities, and threats that exist in a company. The study aims to analyze the implementation of the SWOT analysis in the shrimp culvation business. With SWOT analysis we can analyze the opportunities for the vannamei shrimp business, in this vannamei shrimp cultivation operation, what threats and obstacles we will encounter, know the strengths and advantages that possessed in running this cultivation business.
\end{abstract}

Index Terms - the shrimp cultivation business, strenght, weakness, opportunity, threats.

\section{INTRODUCTION}

Tegal (Central Java) is known as a maritime city, where Tegal is famous for its overflowing marine products. Many marine products from Tegal are traded outside of the Tegal area, such as milkfishes, shrimps, sea fishes, etc. From those things, Tegal has earned the nickname as a Maritime City which has abundant marine products.

One of those business products from the fisheries sector is shrimp. Shrimp (Penaeus spp) is a type of crustacean aquatic animal belonging to the Penaeidae Family. There are several types of shrimp species that have important economic values, like Udang Windu or Tiger Prawns (Penaeus monodon: P. semisulcatus: P. esculentus). Udang Dogol or Endeavour shrimp (Metapenaeus endeavours: M. ennis: M. monoceros). Udang Jerbung/Putih or Banana prawn/White shrimp (Penaeus merguiensis: P. indicus). Udang Krosok or Rainbow shrimp (Parapenaeopsis sculptitis). Udang Ratu/Raja or King prawn (Penaeus latisulcatus). Udang Barong/Karang or Spiny lobsters (Panulirus versicolor) and Vannamei shrimp or Litopenaeus vannamei (Syahfidi, Siregar, \& Hamid, 2010).

The progress in the business from the fisheries sector start to emerge a promising business, that is the Vannamei Shrimp business. Currently, many entrepreneurs have started this business (as individuals or as an organization) on forming the Vannamei Shrimp business. Nowadays, many entrepreneurs and companies are doing this Vannamei Shrimp business to earn more income because of the huge needs from the

market. This also makes MRA Shrimp join in to take the advantage of this market. The expected thing by the entrepreneurs is to take the advantage of this business opportunity by expecting a high income. The vannamei shrimp business is one of the businesses that have a big risk and big costs but have a huge income. The big risks can be seen from a difficult operation because it can be affected by water quality, shrimp fry quality, weather, feed, and others. With large costs from making land using heavy equipment, plastics for the pond mats, huts, electricity costs, worker costs, and others. However, even though it has huge risks and costs, if this business can be run properly, it will be able to return on investment in less than 2 years.

\section{LITERATURE REVIEW}

Kotler (2008) argues that a SWOT analysis is a form of evaluation of all the strengths, weaknesses, opportunities, and threats that exist in a company.

- Strength

Strength is a positive internal condition of the company to improve the competitiveness of the company itself in terms of human resources, skills, soft skills, and other advantages that the company has as well as the market's need to be superior to the competitor.

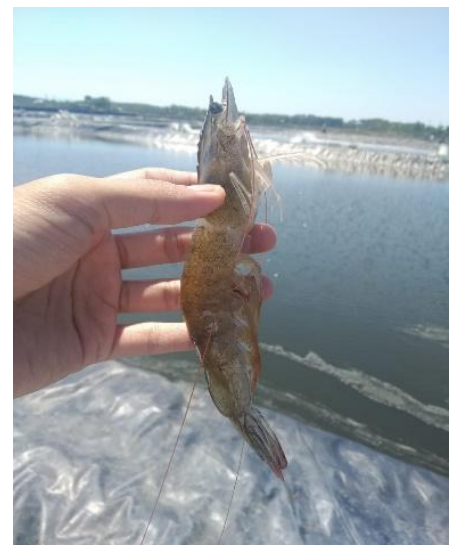

- Weakness

Weakness is a deficiency or negative thing that exists within the company and can be threatening the company's competitiveness. Weakness is limitation and deficiency in a company, both in terms of resources, employee capabilities, and skill mastery which will disturb the running of the company. 


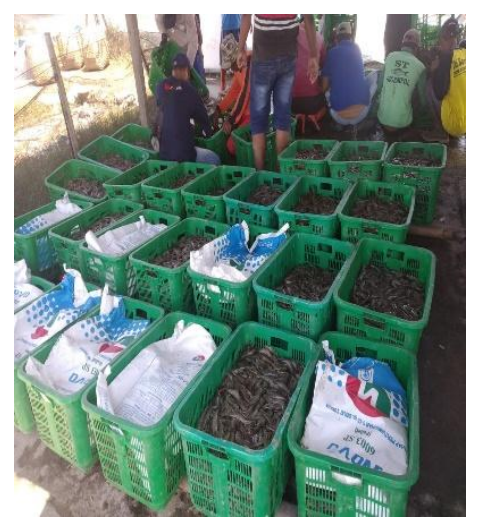

- Opportunity

In this stage, the company must be able to see opportunities from outside of the company and seek opportunities or possible breakthroughs that can be done in business so that the company can be developing in the future.

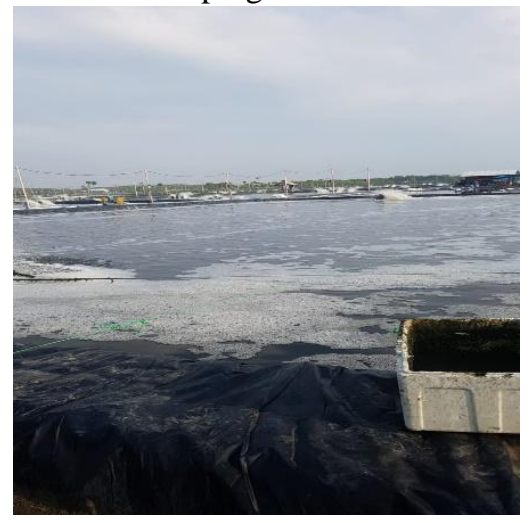

\section{- Threats}

Analyze the challenges or threats that the company needs to face the various poor environmental factors in causing the company to fall on a deterioration. If not addressed, these threats can become a barrier for the company in the present and the future.

\section{RESEARCH METHOD}

The data used are primary. The data collection method used was an observation by making observations and recording the object's behavior. This is done directly at the location of the object of research. The object of research is the cultivator of the vannamei shrimp cultivation business in Tegal, Indonesia. The research is focused on knowing the extent to which the cultivator has implemented the SWOT analysis correctly. So that later, it is expected can get the best results for the business.

\section{RESULT}

\section{- Strength}

Is a strength analysis, the situations, and conditions that are the strengths of a company or organization at this time. What needs to be done in this analysis is that each company or organization needs to assess its strengths and weaknesses compared to its competitors. As with the MRA Shrimp, the strength is the good shrimp result. Looking at the minimum number of dead shrimp, the number of few shrimps with soft skin, a large size compared to the vannamei shrimp cultivators around Tegal, Central Java.

- Weakness

Is a weakness analysis, a situation or condition that is a weakness of an organization or company at this time. This is a way that is done in a company to analyze the obstacles in the company's progress. The weakness that happens in MRA Shrimp at this time is when selling the products, it is only sold to middlemen or small merchant so that there is no other way to sell the product even though the price which given by the middlemen is already high, maintaining water quality in the pond environment is also not optimal so that later this will interfere the cultivation process in the future.

- Opportunity

Is an analysis of opportunities, situations, and conditions that are opportunities outside a company, and provide the opportunities for developing the company in the future. This method is to discover opportunities and even breakthroughs that allow a company to make a progress in the future. The breakthrough made by MRA Shrimp is to carry out good financial management so that it can continue to expand or adding more land, so it can providing better results and make the company grow bigger, initiating the cultivation that can minimize the environmental pollution, then maybe we will start trying to sell small quantities of shrimp to the local people firstly because in Tegal and its surroundings there are unavailable entrepreneurs that sell the products directly to the society.

- Threats

Is an analysis of threats, how to analyze the challenges and threats that must be carried out by a company to deal with various kinds of environmental factors that are unfavorable for the company or organization that will result in deterioration. If the threat cannot be resolved immediately, it will become a barrier for the company in the future. The threats that happen in MRA Shrimp at this time are water and the environment around the business location. This is caused by the waste from cultivation

which pollutes the environment. We have already taken care to reduce this, but the other cultivator sometimes does not care about it. After conducting the SWOT Analysis, MRA Shrimp has now started to overcome the threat by finding solutions to reduce the environmental pollution through the first deposition process. Then we willalso do marketing for a small amount of product to the public first. And we also make the best cultivation process so that the results can be achieved in the cultivation process can get good quality shrimp, low mortality rate shrimp, and even large sizes shrimp can be obtained.

MRA Shrimp should pay attention to the SWOT analysis. With this, we can analyze the opportunities for the vannamei shrimp business, in this vannamei shrimp cultivation operation, what threats and obstacles we will encounter, know the strengths and advantages that possessed in running this cultivation business, we can even find out what our lack or weaknesses in running this business practice activity carried out by MRA Shrimp. 


\section{REFERENCES}

[1] Bohlander, G., \& Snell, S. (2010). Principles of Human Resource, Management $(\mathrm{OH}$ : South- Western - Cengage Learning).

[2] Brigham, E. ., \& Houston, J. . (2011). Dasa- Dasar Manajemen Keuangan, Edisi Kese(Diterjemahkan oleh Ali Akbar Yulianto. Jakarta: Salemba Empat).

[3] David, F. R. (2006). Manajemen Strategi, Buku 1, Ed(Jakarta: Salemba Empat).

[4] Gunawan, K. (2018). Peran Studi Kelayakan Bisnis Dalam Peningkatan UMKM, 2(2), 6-11.

[5] Haryadi, W., Kurniawansyah, \& Rismayanti. (2017). Analisis Faktor-faktor yang Memengaruhi Pendapatan Usaha Tambak Udang Vaname di Dusun Labuhan Terata Desa Labuhan Kuris Kecamatan Lape Kabupaten Sumbawa, 14(2), 172-186.

[6] Heizer, J., \& Render, B. (2015). Manajemen Operasi : Manajemen Keberlangsungan dan Rantai Pasokan, edisi 11(Salemba Empat, Jakarta).

[7] Joesyiana, K. (2019). Penerapan Metode Pembelajaran Observasi Lapangan Pada Mata Kuliah Manajemen Operasional. Journal of Chemical Information and Modeling, 53(9), 1689-1699.

[8] Kotler, P. dan K. lane K. (2012). Marketing Management -14/E. Harlow, Pearson Education., (Pearson Education.).

[9] Mansyur, A., \& Rangka, A. (2008). Potensi Dan Kendala Pengembangan Budidaya Udang Vaname Di Sulawesi Selatan. Media Akuakultur, volume $3 \mathrm{n}, 11-14$.

[10] Mumuh, M. (2010). Manajemen Sumber Daya Manusia (Sdm) Ritel Dalam Meningkatkan Kinerja Perusahaan. Jurnal Ilmiah Ranggagading, 10(2), 164-170.

[11] Natalia, D., \& Nurozy. (2012). Kinerja Daya Saing Produk Perikanan Indonesia Di Pasar Global. Buletin Ilmiah Litbang Perdagangan, 6(1).

[12] Nisak, Z. (2004). Analisis SWOT Untuk Menentukan Strategi Kompetitif.

[13] Omsa, S. (2017). Pengaruh Penerapan Praktek- Praktek Manajemen Strategis. Prosiding Seminar Hasil Penelitian (SNP2M), 258- 263.

[14] Priangani, A. (2013). Mempekuat Manajemen Pemasaran Dalam Konteks. Jurnal Kebangsaan, 2(4), 1-9.

[15] Syahfdi, O. F., Siregar, M. A., \& Hamid, A. (2010). Analisis permintaan pasar ekspor terhadap produk udang beku indonesia. Agrica (Jurnal Agribisnis Sumatera Utara), 3(2), 8-1 